\title{
Incidence and Public Health Risk Assessment of Toxic Metal Residues (cadmium and lead) in Liver and Kidney of Ovine and Bovine from Algeria
}

\author{
Wahiba ZENAD ${ }^{1,2 *}$; Amel BENATALLAH ${ }^{1}$; Mohamed ZAOUANI ${ }^{1,3}$; Sofiane BOUDJELLABA ${ }^{1,4}$; Lynda \\ AINOUZ ${ }^{1,5}$; Meriem Hind Ben MAHDI ${ }^{1,2}$, Ali BENOUADAH ${ }^{5}$ \\ ${ }^{1}$ Higher National Veterinary School, Rue Issad Abbes, Oued Smar, Algiers 16000, Algeria \\ Issad Abbes Street, Oued-Smar, Algiers, Algeria \\ ${ }^{2}$ Research Laboratory -"Health and Animal Productions", Higher National Veterinary school of Algiers, Algeria \\ ${ }^{3}$ Research Laboratory of Food Hygiene and Quality Insurance System (HASAQ), Higher National \\ Veterinary School, of Algiers, Algeria \\ ${ }^{4}$ Research Laboratory Management of Local Animal Resources (GRAAL), Higher National Veterinary \\ School, of Algiers, Algeria \\ ${ }^{5}$ Laboratory of Biology and Animal Physiology, ENS Kouba, Algiers, Algeria \\ ${ }^{5}$ Laboratories of characterization and valorization of the natural product Faculty of Nature and Life \\ Science, University El Bachir El Ibrahimi, Bordj Bou Arreridj, Algeria. \\ * corresponding author: w.zenad @ensv.dz
}

Bulletin UASVM Veterinary Medicine 77(2)/2020

Print ISSN 1843-5270; Electronic ISSN 1843-5378

doi:10.15835/buasvmen-vm:2020.0002

\begin{abstract}
This study intended to establish if $\mathrm{Cd}$ and $\mathrm{Pb}$ in the livers and kidneys of bovine and ovine slaughtered in the study area exceeded to concentrations maximum limit proposed by the European Commission (EC) 2006. After digestion of samples, Cadmium and lead concentrations were determined by Graphite Furnace Atomic Absorption Spectrophotometry (GFAAS). The results of our study have shown that lead and cadmium concentrations depend on age and species. The average fresh weight levels of liver and kidneys of bovine animals were about $(0.319 \mathrm{mg} /$ $\mathrm{kg}$ and $0.337 \mathrm{mg} / \mathrm{kg}$ ) for $\mathrm{Cd}$ and $(0,502 \mathrm{mg} / \mathrm{kg}$ and $0.497 \mathrm{mg} \mathrm{kg}$ ) for $\mathrm{Pb}$, while in ovine, mean concentrations in the liver and kidneys were $(0,241 \mathrm{mg} / \mathrm{kg}$ and $0.232 \mathrm{mg} / \mathrm{kg})$ for $\mathrm{Cd}$ and $(0.259 \mathrm{mg} / \mathrm{kg}$ and $0.265 \mathrm{mg} / \mathrm{kg})$ for $\mathrm{Pb}$. Concentrations above the maximum limit proposed by the EC 2006 for $\mathrm{Pb}$ and Cd have been detected in some liver and kidney samples from bovine older than 4 years and in ovine over 1 year old .Statistical analysis revealed a very significant $(\mathrm{P}<0.01)$ difference in $\mathrm{Cd}$ concentrations in the liver and kidneys between age groups and species.
\end{abstract}

Keywords: Lead, cadmium, bovine, ovine, liver, kidney.

\section{Introduction}

Lead $(\mathrm{Pb})$ and cadmium (Cd) are cumulative toxic metals thus, their widespread use and cumulative effect could lead to a severe environmental contamination and many public health problems (Saratug et al., 2003 and Custer et al., 2004). They are transmitted from mobile and stationary sources into the air and may reach to human food
(Sharkawy and Amal, 2003). Industrial and urban activities generate the accumulation of metallic waste in soils, which can be transferred to plants and therefore to animals, hence the importance of knowledge of soil-plant transfer- terrestrial organisms.

Ruminants bioaccumulate these toxic elements and are therefore the most exposed to $\mathrm{Pb}$ 
and $\mathrm{Cd}$, due to the grazing structure. Heavy metals have the ability to lodge in the reticulum of ruminants and provide a reservoir, which is continually absorbed into the bodies of these animals (Radostitis et al., 2007).

Ovine and bovine are the main sources of red meats, which have the potential to induce toxic human exposure. Offal's, especially liver and kidneys are the targeted organs for the bioaccumulation of metallic elements, and thus constitute a significant source of exogenous food intake. Differences in contamination levels of internal organs (kidney and liver) depend on the species and age of animals (Hecht, 1983; Kreïowska-Kuïas, 1994; Studzinski et al., 1992).

In Algeria, offal consumption is very important given its low cost and is part of some traditional diets. The level of heavy metal impregnation in the meat producing animal population is poorly investigated.

The aim of our study was to determine the levels of $\mathrm{Pb}$ and $\mathrm{Cd}$ in kidney and liver samples taken from bovine and ovine slaughtered in the country, as well as the potential risks of consumption of these organs.

\section{Materials and methods Ethical approval}

Ethical approval is not applicable to this study as liver and kidney samples used for the analysis of heavy metals were collected from slaughtered bovine and ovine in Algeria.

\section{Reagents}

The chemicals and reagents used were of analytical high quality and they were mostly from Sigma (St. Louis, MO) and Merck (Mannheim, Germany). The HNO3 was of suprapure quality (E. Merck, Darmstadt), standard solutions of lead and cadmium were purchased from Merck (Darmstadt, Germany) and double distilled deionized water (Milli-Q Millipore $18.2 \mathrm{M} \Omega-\mathrm{cm}$ resistivity) was used for all dilutions.

\section{Collection of Samples}

A total of one hundred and eighty fresh liver and kidney samples were collected from bovine $(n=$ $80)$ and ovine $(n=100)$ from the slaughterhouses in East and North of Algeria, from October 2016 to February 2017.The samples were taken only from healthy animals of three age groups: less than 12 months, between 1 to 4 years and over 4 years.

\section{Mineralization of samples}

Samples mineralization was done according to European Standard EN 13805 (2002). Briefly, 100g of each organ for analysis were stored in plastic falcon tubes and placed in a cooler box. Samples in the box were stored at $-20^{\circ} \mathrm{C}$ during transfer to the laboratory up until sample preparation and analyses. At the laboratory the samples were freed of fat, major blood vessels and tendons, and homogenised.

All plastic and glassware were cleaned by soaking in diluted HNO3 $(10 \% \mathrm{v} / \mathrm{v})$ and rinsed with distilled water prior to use. The element standard solutions used for calibration were prepared by diluting stock Heavy-metal levels in examined tissues were measured according to the method described by Finerty et al. (1990). In summary, $1 \mathrm{~g}$ of each sample was mixed with $10 \mathrm{~mL} \mathrm{3:2}$ HNO3 (65\%v/v): $\mathrm{HClO} 4(70 \% \mathrm{v} / \mathrm{v})$. The mixture was allowed to digest overnight in the cold and later heated for $3 \mathrm{~h}$ in a water bath at $70^{\circ} \mathrm{C}$ with swirling at $30 \mathrm{~min}$ intervals to ensure complete digestion. After cooling, the digest was transferred into $20 \mathrm{~mL}$ standard asks, rinsing with de-ionized water and made up to the mark. Prepared sample solutions were kept in acid-leached polyethylene bottles at room temperature until metal analyses.

The samples were firstly dried and then thermally degraded at $750^{\circ} \mathrm{C}$.

\section{Calibration and Assay of Heavy Metals}

Before each series of measurements, commercialized calibration solutions were prepared $(6$ for $\mathrm{Pb}$ and $\mathrm{Cd}$ and 5 for $\mathrm{Hg}$ ); then, calibration curves were established. For $\mathrm{Pb}$ and $\mathrm{Cd}$, a standard (PerkinElmer Pure reference N9300281) was used at a concentration of $100 \mathrm{mg} / \mathrm{L}$ for $\mathrm{Hg}$; a standard (AccuStandard reference AA34N-5) was used at a concentration of $1000 \mathrm{mg} / \mathrm{L}$. Heavy metals concentrations were assessed using Atomic Absorption Spectroscopy (A.A.S) (UNICAM 929). For each heavy metal, there was a specific hollow cathode lamp and the machine was set at a particular wavelength for the metal to be analysed. The content of heavy metals in the assessed tissues was expressed in $\mathrm{mg} / \mathrm{kg}$ of fresh mass. The dosage of $\mathrm{Cd}$ was carried out with a wavelength of 228, $8 \mathrm{~nm}$ and temperature programming: at $100^{\circ} \mathrm{C}, 800^{\circ} \mathrm{C}$ and $900^{\circ} \mathrm{C}$. In contrast, the dosage of $\mathrm{Pb}$ was carried out with a wavelength of $217 \mathrm{~nm}$ and programmed at the same temperature. The calibration of the device was performed by the embodiment of 10 blank measurements. 


\section{Quality control of the analysis}

Analytical performances were verified by processing Certified Reference Materials: For Pb and $\mathrm{Cd}$, we used the cereals and derivatives BIPEA with internal reference number (15350395) and a known concentration of these metals $(\mathrm{Cd}=0.406$ $\mathrm{mg} / \mathrm{kg}$ w.w), and $(\mathrm{Pb}=0.851 \mathrm{mg} / \mathrm{kg}$ w.w). The results were in good agreement with the certified values located in these intervals: $0.3046-0.5075$ for Cd, and 0.6128-0.10892 for Pb.

Statistical analysis was performed with Statview ${ }^{\circledR}$ software (Version 4.55, California - USA). The heavy metals concentrations were described by their means as well as their minimum and maximum values (the extent). The results were performed as mean \pm standard error $(\mathrm{M} \pm \mathrm{SE})$. The one way analysis of variance (ANOVA) was performed to compare the bioaccumulation of $\mathrm{Cd}$ and $\mathrm{Pb}$ in the liver and kidneys of bovine and ovine species. $Z$-test was used to determine differences between groups. The difference was considered significant at $P<0.05$.

\section{Results and discussions}

The objective of this study was to determine $\mathrm{Pb}$ and $\mathrm{Cd}$ residues in cattle and sheep offal (liver and kidney), the results were expressed in mg / kg.

Over of 180 samples (all samples combined), 48 samples (26.66\%) contained high levels of $\mathrm{Pb}$ and $\mathrm{Cd}$ residues, with values exceeding the European certified reference value of $(0.5 \mathrm{mg} /$ $\mathrm{kg}$ ) for lead in the liver and kidneys and $0.5 \mathrm{mg} /$ $\mathrm{kg}$ and $1 \mathrm{mg} / \mathrm{kg}$ for $\mathrm{Cd}$ in the liver and kidneys respectively

Offal of cattle was more affected than that of sheep. In fact, out of 180 collected samples, 48 presented concentrations exceeding the EC limits, only 13 out of 100 samples were contaminated in sheep. Livers are the most contaminated compared to kidneys with a rate of $16,66 \%(30 / 180)$ against $10 \%(18 / 180)$ for the kidney (Table 1$)$.

\section{Cadmium}

The mean concentrations of Cd levels in the liver and kidney of bovine obtained in our study were $(0.319 \pm 0.040 \mathrm{mg} / \mathrm{kg}$ and $0.337 \pm 0.077 \mathrm{mg}$ / kg) respectively. The highest concentrations were observed in kidney with a maximum level of $1.865 \mathrm{mg} / \mathrm{kg}$ followed by liver $(0.82 \mathrm{mg} / \mathrm{kg})$.

The mean concentration of $\mathrm{Cd}$ in liver was higher among the age group>4years with 144 concentration of $(0.474 \mathrm{mg} / \mathrm{kg} \pm 0.055)$ in comparison

Table 1: The Lead and Cadmium concentration of liver and kidney of slaughtered bovine and ovine in Algeria (mgkg ${ }^{-1}$ fresh weight).

\begin{tabular}{|c|c|c|c|c|c|c|c|c|c|c|c|c|}
\hline & \multicolumn{6}{|c|}{ Lead } & \multicolumn{6}{|c|}{ Cadmium } \\
\hline & \multicolumn{3}{|c|}{ Liver } & \multicolumn{3}{|c|}{ Kidney } & \multicolumn{3}{|c|}{ Liver } & \multicolumn{3}{|c|}{ Kidney } \\
\hline & Bovine & Ovine & $P$ & Bovine & Ovine & $P$ & Bovine & Ovine & $P$ & Bovine & Ovine & $P$ \\
\hline $\begin{array}{l}\text { No of } \\
\text { samples }\end{array}$ & 40 & 50 & & 40 & 50 & & 40 & 50 & & 40 & 50 & \\
\hline $\begin{array}{l}\text { EC limits } \\
\left(\mathrm{mg}^{2} \mathrm{~kg}^{1}\right)\end{array}$ & 0.5 & 0.5 & & 0.5 & 0.5 & & 0.5 & 0.5 & & 1 & 1 & \\
\hline $\begin{array}{l}\text { Mean } \pm E S \\
\left(\mu \mathrm{g} \cdot \mathrm{kg}^{-1}\right)\end{array}$ & $\begin{array}{c}0.502 \\
\pm \\
0.051\end{array}$ & $\begin{array}{c}0.259 \\
\pm \\
0.021\end{array}$ & $<0.001$ & $\begin{array}{c}0.497 \\
\pm \\
0.07\end{array}$ & $\begin{array}{c}0.265 \\
\pm \\
0.030\end{array}$ & 0.0033 & $\begin{array}{c}0.319 \\
\pm \\
0.04\end{array}$ & $\begin{array}{c}0.241 \\
\pm \\
0.022\end{array}$ & NS & $\begin{array}{c}0.337 \\
\pm \\
0.077\end{array}$ & $\begin{array}{c}0.232 \\
\pm \\
0.030\end{array}$ & NS \\
\hline Minimum & 0.078 & 0.001 & & 0.009 & 0.005 & & 0.024 & 0.030 & & 0.019 & 0.015 & \\
\hline Maximum & 1.45 & 0.580 & & 1.475 & 0.880 & & 0.82 & 0.605 & & 1.856 & 1.019 & \\
\hline $\begin{array}{l}\text { No of } \\
\text { samples } \\
\text { exceeding } \\
\text { the EC } \\
\text { limits }\end{array}$ & 12 & 4 & & 9 & 4 & & 10 & 4 & & 4 & 1 & \\
\hline
\end{tabular}


to the age category $\leq 4$ years, where the concentration of Cd was $0.143 \mathrm{mg} / \mathrm{kg} \pm 0,018$.

In the kidney, the mean concentrations of Cadmium were also higher among the age group $>$ 4 years with the concentration $(0.589 \mathrm{mg} / \mathrm{kg} \pm 0.1)$ in comparison to the age category $\leq 4$ years, where the concentration of $\mathrm{Cd}$ was $(0.085 \pm 0.01)$ (Table 1 and Table 2).

For ovine, mean Cd concentrations were $0.241 \pm 0.022 \mathrm{mg} / \mathrm{kg}$ in liver samples and $0.232 \pm$ $0.033 \mathrm{mg} / \mathrm{kg}$ in kidney samples. Nevertheless, only 4 (8\%) liver samples and 1 (2\%) kidney samples with a maximum level of $0.605 \mathrm{mg} / \mathrm{kg}$ and 1.019 $\mathrm{mg} / \mathrm{kg}$ respectively, containing $\mathrm{Cd}$ concentrations greater than the limits proposed by EC were found.

The mean Cadmium concentrations for ovine, young and aged were $0.161 \pm 0,018 \mathrm{mg} / \mathrm{kg}$ and $0.321 \pm 0.034 \mathrm{mg} / \mathrm{kg}$ respectively in the liver samples, and $0.145 \pm 0.021 \mathrm{mg} / \mathrm{kg}$ and $0.319 \pm$ $0.058 \mathrm{mg} / \mathrm{kg}$ respectively in the kidney samples (Tab. 1 and Tab. 3).

\section{Lead}

The obtained results (Table 1 ) revealed mean lead concentrations in the liver of bovine and ovine, were $(0.502 \pm 0.051 \mathrm{mg} / \mathrm{kg}$ and $0.259 \pm 0.021 \mathrm{mg} /$ $\mathrm{kg}$ ), respectively. while in the kidney, mean $\mathrm{Pb}$ values in the kidney of bovine and ovine, were respectively, $(0.497 \mathrm{mg} / \mathrm{kg} \pm 0,077$ and $0.265 \pm 0,03 \mathrm{mg} /$ $\mathrm{kg}$ ). the samples examined exceeded the limits imposed by the European Regulations in livers and kidneys.

The mean $\mathrm{Pb}$ concentrations were $0.27 \pm 0.024$ $\mathrm{mg} / \mathrm{kg}$ and $0.734 \pm 0.067 \mathrm{mg} / \mathrm{kg}$ in the liver samples, and $0.254 \mathrm{mg} / \mathrm{kg} \pm 0,01$ and $0.739 \mathrm{mg} / \mathrm{kg} \pm 0.132$, in the kidney samples for young and aged cattle, respectively. Whereas in sheep, concentrations in liver samples were $0.197 \pm 0.024 \mathrm{mg} / \mathrm{kg}$ and 0.32 $\pm 0.03 \mathrm{mg} / \mathrm{kg}$, and in the kidney, we obtained the mean rates of $0.206 \pm 0.024 \mathrm{mg} / \mathrm{kg}$ and 0.324 $\pm 0.053 \mathrm{mg} / \mathrm{kg}$, for young and aged animals, respectively (Tab. 2 and Tab. 3).

This study revealed that $\mathrm{Pb}$ and $\mathrm{Cd}$ have been detected in all tissues analysed. In general, the liver contained more $\mathrm{Pb}$ and $\mathrm{Cd}$ concentrations than the kidney.

From these results, very significant differences were observed between the accumulation of

Table 2: The Lead and Cadmium concentration of liver and kidney of slaughtered bovine in Algeria in relation to the age $\left(\mathrm{mgkg}^{-1}\right.$ fresh weight) (Mean $\left.\pm \mathrm{SE}\right)$.

\begin{tabular}{lcccccc}
\hline & \multicolumn{2}{c}{ Lead } & \multicolumn{3}{c}{ Cadmium } \\
\cline { 2 - 7 } & $\begin{array}{c}\leq \text { 4 years } \\
\text { (Males) }\end{array}$ & $\begin{array}{c}>\text { 4 years } \\
\text { (Females) }\end{array}$ & $\boldsymbol{P}$ & $\begin{array}{c}\leq \text { 4 years } \\
\text { (Males) }\end{array}$ & $\begin{array}{c}>\text { 4 years } \\
\text { (Females) }\end{array}$ & $\boldsymbol{P}$ \\
\hline Liver & $0.270 \pm 0.024^{\mathrm{a}}$ & $0.734 \pm 0.067^{\mathrm{a}}$ & $<0.0001$ & $0.143 \pm 0.018^{\mathrm{a}}$ & $0.474 \pm 0.055^{\mathrm{a}}$ & $<0.0001$ \\
\hline Kidney & $0.254 \pm 0.031^{\mathrm{a}}$ & $0.739 \pm 0.132^{\mathrm{a}}$ & 0.001 & $0.085 \pm 0.01^{\mathrm{b}}$ & $0.589 \pm 0.132^{\mathrm{a}}$ & 0.0005 \\
\hline
\end{tabular}

$\left({ }^{a, b}\right)$ Change in latter in the same column indicate significant difference between concentration of Lead and cadmium.

Table 3: The Lead and Cadmium concentration of liver and kidney of slaughtered ovine in Algeria in relation to the age $\left(\mathrm{mgkg}^{-1}\right.$ fresh weight) (Mean $\left.\pm \mathrm{SE}\right)$.

\begin{tabular}{lcccccc}
\hline & \multicolumn{2}{c}{ Lead } & \multicolumn{4}{c}{ Cadmium } \\
\cline { 2 - 7 } & $\begin{array}{c}\leq \text { 1 year } \\
\text { (Males) }\end{array}$ & $\begin{array}{c}\text { > 1 year } \\
\text { (Females) }\end{array}$ & $\boldsymbol{P}$ & $\begin{array}{c}\leq \text { 1 year } \\
\text { (Males) }\end{array}$ & $\begin{array}{c}>\text { 1 year } \\
\text { (Females) }\end{array}$ & $\boldsymbol{P}$ \\
\hline Liver & $0.197 \pm 0.024^{\mathrm{a}}$ & $0.32 \pm 0.03^{\mathrm{a}}$ & 0.002 & $0.161 \pm 0.018^{\mathrm{a}}$ & $0.321 \pm 0.034^{\mathrm{a}}$ & 0.0001 \\
\hline Kidney & $0.206 \pm 0.024^{\mathrm{a}}$ & $0.324 \pm 0.053^{\mathrm{a}}$ & 0.0468 & $0.145 \pm 0.021^{\mathrm{a}}$ & $0.319 \pm 0.058^{\mathrm{a}}$ & 0.0068 \\
\hline
\end{tabular}

$\left({ }^{a, b}\right)$ Change in latter in the same column indicate significant difference between concentration of Lead and cadmium. 
heavy metal residues $(\mathrm{Cd}, \mathrm{Pb})$ in organs (liver and kidney) and animals' species (bovine and ovine)

From these results, clear interspecies differences in the accumulation of heavy-metal residues between cattle and sheep tissues were observed. Cattle, especially, had higher levels of both $\mathrm{Cd}$ and $\mathrm{Pb}$ than sheep did. The mean $\mathrm{Cd}$ concentrations recorded in our study were similar to those found by Al-Naemi (2011) in Iraq. Our results are in contrast with the ones found by Khalafallah et al. (2015); Bala et al. (2012); Akan et al. (2010), but they were lower than those obtained by Swaileh et al. (2009) and Mariam et al. (2004), in which the limits are higher.

The presence of $\mathrm{Cd}$ in animal tissues, especially livers and kidneys, was strongly related to Cd levels in animal feed (Kreuzer et al., 1988). This was related to the differences in exposure, and other factors such as: age, species and food composition. Therefore, its presence in the samples constitutes a risk for public health.

$\mathrm{Pb}$ was considered one of the main environmental pollutants and one of the causes of accidental poisoning for domestic animals in particular. Lead absorbed accumulates in the bones, liver and kidneys. Lead levels in liver and kidneys have been generally related to lead levels in animal feed (Kreuzer et al., 1988; Sharma et al., 1982; Vreman et al., 1986).

Cattle were more contaminated by $\mathrm{Pb}$ with a percentage of $22 \%$ and $30 \%$ in the kidney and liver respectively than sheep with a percentage of $8 \%$ each in the liver and kidney.

Higher $\mathrm{Pb}$ concentrations were found in kidneys and livers of both species (bovine and ovine). These concentrations were significantly higher than the limits set by the European Commission (EC) (0.5 mg / kg).

The lead levels found in this study were similar to most of the literature data as Al-Naemi, (2011) in Iraq, AbouDounia (2008) in Egypt, Kazemeini et al., (2010). Our result is in contrast with the ones found by of Nriagu et al. (2009) in Jamaica; Khalafallah et al. (2015); Bala et al. (2013) in Niger, in which the limits are higher. The results showed a very significant $(\mathrm{P}<0.05)$ difference between $\mathrm{Cd}$ and $\mathrm{Pb}$ levels in the studied organs due to different age categories. A positive correlation was found between age and the content of the studied metals. The highest rate of $\mathrm{Cd}$ has been found in kidney and liver in cattle samples, ranging over 4 years old. As for sheep, the highest rate was found in the age group $>1$.

The highest $\mathrm{Pb}$ concentrations found in cows in the liver and kidneys would have been related to the age group $>4$ years at intake. Concerning sheep, the highest rates were observed in the age group between 1 and 2 years. Our results have confirmed those of other authors (Salisbury et al. 1991; Lopez Alonso et al. 2000, 2002), who also demonstrated that there was a positive correlation between age, $\mathrm{Cd}$ and $\mathrm{Pb}$ concentrations in organs, which explains that the nature of these laters were highly accumulative.

In our study, the highest levels of $\mathrm{Cd}$ and $\mathrm{Pb}$ were recorded in breeding dairy cows between 5 and 9 years older. These high levels can be explained by the high doses of mineral supplements received by these cows during gestation. Thus, minerals have been known for their interactions with $\mathrm{Cd}$, such as calcium, zinc, copper, iron, and selenium (Andersen et al., 1997). Studies have shown that exposure to $\mathrm{Cd}$ and $\mathrm{Pb}$ during pregnancy and lactation can have deleterious effects in offspring, resulting in developmental and behavioural deficits and adverse reproductive effects as $\mathrm{Cd}$ induces a decrease in relative testes weight and plasma testosterone, indicating interference with spermiogenesis and steroidogenesis (Pillai et al. 2012; Bonda et al. 2004; Luo et al. 2015).

Cattle and other animals constitute bio indicators of environmental contamination of heavy metals (Miranda et al., 2009). The results of our study reflect excessive levels of exposure to heavy metals. The consumption of foods produced in contaminated areas and the ingestion or inhalation of contaminated particles are two principal exposure pathways of these potentially toxic metals in man. A close correlation has been reported between the heavy metals concentrations in bovine tissues and that in soil, food and drinking water (Sedki et al. 2003; Qiu et al., 2008).

It was therefore possible that the animals in our study (cattle and sheep) were from a polluted area and dietary habits lead to the bioaccumulation of heavy metals in the liver and kidneys. In general, heavy metals such as $\mathrm{Pb}$ and $\mathrm{Cd}$ have slow removal rates, so that harmful levels could accumulate in tissues after prolonged exposure to low levels in the environment.

The consumption of offal's, particularly the liver, was well known in Algeria related to its high 
iron content and also a major source of vitamins, proteins and lipids. This can result in indirect ingestion of $\mathrm{Pb}$ and $\mathrm{Cd}$ which constitute a serious problem for public health.

\section{Conclusion}

The results of this study revealed the presence of heavy metals (lead and cadmium) at different concentrations in all samples (liver and kidneys) analysed. Indeed, liver samples of cattle and sheep contained higher concentrations of $\mathrm{Cd}$ and $\mathrm{Pd}$ than the kidney.

As well as, lead and cadmium levels of liver and kidney samples in cattle were higher than liver and kidney samples in sheep. This was related to the differences of age of animals studied because age has a significant influence on the accumulation of toxic metals. Moreover, the effect of sex and age on heavy metal exposure has been well confirmed. On the other hand, the concentrations of these metals were high in these organs and the consumption of large quantities represents a potential health risk. Therefore, accurate care and sanitary inspection of livestock in these areas were recommended.

Acknowledgments. This research did not receive any specific grant from funding agencies in the public, commercial, or not-for-profit sectors.

\section{References}

1. Akan JC, Abdulrahman FI, Sodipo OA, Chiroma YA (2010). Distribution of heavy metals in the liver, kidney and meat of beef, mutton, caprine and chicken from kasuwashanu market in Maiduguri. Res J ApplSciEngTechnol8:743-748.

2. Al-Naemi H (2011). Estimation of lead and cadmium levels in muscles, liver and kidney of slaughtered cattle in Mosul City. Mesopotamia J Agric 39:8-16.

3. Abou-Donia MA (2008). Lead concentrations in different animal muscles and consumable organs at specific localities in Cairo. Global Veterina. 2:280-284.

4. Anderson H, Petersson-Grawe K, Londqvist E, Luthman J, Oskarsson A, Olson L (1997). Low- level cadmium exposure of lactating rats causes alterations in brain serotonin levels in the offspring. NeurotoxicolTeratol; 19: 105-15.

5. Bala A, Suleiman N, Junaidu AU, Salihu MD, Ifende VI, Saulawa MA, Magaji AA, Faleke 00, Anzaku SA (2013a). Detection of Lead (Pb), Cadmium (Cd), Chromium(Cr) Nickel (Ni) and Magnesium Residue in Kidney and Liver of Slaughtered Cattle in Sokoto Central Abattoir, Sokoto State, Nigeria. Int. J. of Livestock Research 3:77-81

6. Bala A, Saulawa MA, Junaidu AU, Salihu MD, Onifade KI, Magaji AA, Anzaku SA, Faleke O0, Musawa AI, Mohammed M (2012b). Detection of cadmium (Cd) residue in kidney and Liver of slaughtered cattle in Sokoto Central Abattoir, Sokoto State, Nigeria. J Vet Adv. 2:168-172.

7. Bonda E, Wlostowski T, Krasowska A (2004).Testicular toxicity induced by dietary cadmium is associated with decreased testicular zinc and increased hepatic and renal metallothionein and zincin the bank vole (Clethrionomysglareolus).Biometals17:615-624.

8. Custer TW, Cox E, Gray B (2004). Trace elements in moose (Alces alces) found dead in north-western Minnesota, USA. Sci. Total Environ. 330, 81-87.

9. Commission of the European Communities (2006). Commission Regulation (EC) No. 1881. Setting maximum levels for certain contaminants in foodstuffs. Off J Eur Comm L364:5.

10. Finerty MW, Madden D, Feagly E, Orodner M (1990). Effect of environment and seasonality on metal residues in tissues of wild and pond raised craysh in southern Louisiana. Archives of Environmental Contamination and Toxicology 19: 94-99.

11. Hecht H (1983). Toxische Scwermetalle in Fleish und Innerein verschie- dener Tierarten. Fleischwitschaft, 63, 544-558

12. Kazemeini HR, Rahimi E, Nozarpour N (2010). Cadmium concentration in muscles, liver and kidneys of sheep slaughtered in Iran. Toxic and indust Health, SAGE journals online 26(5)259.

13. Khalafalla FA, Abdel-Atty NS, Rofaida B, Abo-Elsoud (2015). Assessment of heavy metal residues in retail meat and offals. Journal American Science 11(5):50-54. (ISSN: 1545-1003).

14. Kreïowska-Kuïas M (1994). Zanieczyszczenia chemiczne surowcow i zywnosci pochodzenia zwierzçcego. Mater. 25 Sesji Nauk. „Postçpy w technologii zywnosci”, Lublin 1516.09. AR w Lublinie, 237.

15. Kreuzer W, Rosopulo A, Sell D, Frankenberg J, Koberstein $S$ (1988). Lead and cadmium contents inthe musculature, liver and kidney of slaughter calves. Calves from uncontaminated areas and/or farms that have passed meat inspection. Fleischwirtschaft 71: 339-344.

16. Lopez-Alonso M, Benedito L, Mirada M, Castillo C, Hernandez J, Shore F (2002). Contribution of Cattle products to dietary intake and toxic elements in Galicia, Spain. Food Additives and Contaminants 19: 533-541.

17. Lopez-Alonso M, Benedito JL, Miranda M, Castillo C, Hernandez J, Shore RF (2000). Toxic and trace elements in liver, kidney and meat from cattle slaughtered in Galicia (NW Spain). Food Additives and Contaminants 17: 447457.

18. Luo X, Li L, Ma M, Li R (2015). Effects of low-dose cadmium exposure during gestation and lactation on development and reproduction in rats. Environ SciPollutRes Int 22(14):10569-10579.

19. Mariam, I., Iqbal, S., Nagra, A.S. (2004). Distribution of some trace and macro minerals in beef, Mutton and poultry. Int J Agric Biol 5: 816.

20. Miranda M, Benedito JL, Blanco-Penedo I, Lopez-Lamas C, Merino A, Lopez-Alonso M (2009). Metal accumulation in cattle raised in a serpentine-soil area: relationship 
between metal concentrations in soil, forage and animal tissues. J Trace Elem Med Biol. 23:231-238.

21. Nriagu J, Boughanen M, Linder A, Howe A, Grant C, Rattray $\mathrm{R}$, Vutchkov M, Lalor G (2009). Levels of As, Cd, Pb, Cu, Se and $\mathrm{Zn}$ in bovine kidneys and livers in Jamaica. Ecotoxicol Environ Safety. 72:564-571.

22. Pillai P, Pandya C, Bhatt N, Gupta SS (2012). Biochemical and reproductive effects of Gestational/lactational exposure to lead and cadmium with respect to testicular steroidogenesis, Antioxidant system, endogenous sex steroid and cauda-epididymal functions. Andrologia 44:92-101

23. Qiu CAI, Long M, Liu J, Zhu M, Zhou QZ, De Deng Y, LiY, Tain YJ (2008). Correlation Between heavy metals concentration in cattle tissues and rearing environment. Chinese J Ecol27:202-207.

24. Radostitis OM, Gay, CC, Hinchcliff KW, Constable, PD (2007). "Veterinary Medicine: A Textbook of the Disease of Cattle, Horses, Sheep, Pigs and Goats" (10th ed) Saunders, Elsevier, Spain, pp: 1799-1808.

25. Salisbury CDC, Chan W, Saschenbrecker PW (1991). Multielement concentrations in liver and Kidney tissues from five species of Canadian slaughter animals. J Assoc of Anal Chem 74:87-591.

26. Saratug S, Baker JR, Urbenjapol S, Haswell-Elkins M, Reilly PEB, Williams DJ, Moore MR (2003). A global perspective on cadmium pollution and toxicity in non-occupationally exposed population. Toxicol. Lett. 137, 65-83.
27. Sedki A, Lekouc N, Gamon S, Pinea A (2003). Toxic and essential trace metals in muscle, liver and kidney of bovines from a polluted area of Morocco. Sci Total Environ. 317:201-205

28. Sharma RP, Street JC, Shupe JL, Bourcier DR (1982). Accumulation and depletion of cadmium and lead in tissues and milk of lactating cows fed small amounts of these metals. Journal of Dairy Science 65: 972-979.

29. Sharkawy AA, Amal AM (2003). Lead and cadmium levels in someready-to-eat meat products (shawerma and hamburger) at Assiut City.Assiut Vet. Med. J. 49 (99): 105112.

30. Studzinski T, Walkuska G, Saddour A (1992). Stçzenie olowiu, kadmu, miedzi i cynku w watrobie, nerkach, miçsniach szkieletowych i môzgowiu jagniat i owiec doroslych. Bromat. Chem. Toksykol 25 (4): 355-360.

31. Swaileh KM, Abdul Khaliq AM, Hussein R, Matani M (2009). Distribution of Toxic Metals in Organs of Local Cattle, Sheep, Goat and Poultry from the West Bank, Palestinian Authority Bull Environ Contam. Toxicol 83:265-268 DOI 10.1007/s00128-009-9704-x

32. Vreman, K, Van der Veen NG, Van der Molen EJ, De Ruig WG (1986). Transfer of cadmium, lead, mercury and arsenic from feed into milk and various tissues: chemical and pathological data. Neth J Agric Sci 34: 129-144. 